\title{
Representation of Indonesian women workers: a critical discourse analysis on the newspapers of nationalist-secular and Islamic ideological perspectives
}

\author{
Aris Badara \\ University of Halu Oleo. Kendari Indonesia \\ E-mail: arisbadara71@yahoo.co.id \\ Jamiludin \\ University of Halu Oleo. Kendari Indonesia \\ E-mail: jamiluddin@uho.ac.id \\ DOI: 10.18326/ijims.v10i1.79-101
}

\begin{abstract}
The purpose of this study is to reveal the representation of women workers in newspaper news discourse that follows the nationalist-secular ideology and the Islamic ideology perspectives. The method of this research is a qualitative content analysis that views the text as a symbolic message and requires interpretations according to the context. Complementing the research method, a critical discourse analysis approach is also used. The subjects of this research are female workers found in newspaper news discourse with Islamic ideology as a background and newspapers with nationalist-secular ideology. Data were analyzed through critical discourse analysis techniques in the following steps: description, interpretation, and explanation. This research still considers checking reliability and validity.
\end{abstract}


Data analysis is also complemented by the confirmation of linguists and peers (triangulation of sources). The main findings of this study show that the practice of discourse in the Rakyat Merdeka Newspaper (RMN), which follows the nationalist-secular ideology perspective, represents marginal women. In RMN, the representation is used as a plea for the actions and traits of male actors or employers. The motive revealed from this phenomenon is to follow the demand of the market. On the other hand, the Republika Newspaper (RN), which tends to follow the Islamic ideology perspective, represents the motive of advocacy for women workers. This is the implication of the values of Islamic ideology carried out by the $\mathrm{RN}$ as mentioned in its vision and mission. The findings are also the antithesis of the view that Islam isolates women in the social sphere of society.

Tujuan penelitian ini ialah mengungkap representasi pekerja perempuan pada wacana berita surat kabar yang berpresfektif ideologi nasionalis-sekuler dan surat kabar yang berpersfektif ideologi Islam. Metode penelitian ini ialah analisis isi kualitatif yang memandang teks sebagai suatu pesan simbolik yang perlu diinterpretasi sesuai dengan konteks. Melengkapi metode penelitian tersebut, digunakan pendekatan analisis wacana kritis. Latar penelitian ini ialah pekerja perempuan yang terdapat pada wacana berita surat kabar yang megusung nilainilai ideologi Islam dan surat kabar yang mengusung ideologi nasionalis-sekuler. Data dianalisis melalui teknik analisis wacana kritis dengan langkah: deskripsi, interpretasi, dan eksplanasi. Penelitian ini tetap mempertimbangkan checking the reliability dan checking the validity. Analisis data dilengkapi comfirmability melalui pakar bahasa dan sejawat (trianggulasi sumber). Temuan utama penelitian ini menunjukkan bahwa praktik wacana pada berita Surat kabar Rakyat Merdeka yang berideologi nasionalis-sekuler merepresentasi perempuan secara marjinal. Representasi tersebut dijadikan pleidoi atas perlakuan majikan. Motif yang diungkap ialah mengikuti permintaan 'pasar'. Adapun Surat Kabar Republika, cenderung ke ideologi Islam, merepresentasi pekerja perempuan secara apa adanya dengan motif untuk melakukan advokasi. Hal tersebut merupakan implikasi dari nilai-nilai ideologi Islam yang diemban oleh surat Kabar tersebut. Temuan tersebut juga menjadi antitesis dari pandangan yang menyatakan Islam melakukan pengucilan terhadap perempuan dalam sosial-kemasyarakatan.

Keywords: Critical discourse analysis; Women representation; Discourse of news on newspapers; Ideology perspectives 


\section{Introduction}

Discourse analysis considers that language can be utilized for certain purposes, both for ideological and political interests. In line with that, Munawar stated that language is a social process that is socially produced and conditioned. ${ }^{1}$ It includes language in the discourse of news on newspaper, as stated by Tebba who agreed with the news delivered by the media at the time of ideological, political, and business complaints. ${ }^{2}$ The ideology of the mass media is determined by the background of the owner, both the religious background and the values he/she lives with.

To uncover the ideology and representation behind the discourse of news in newspapers, this research uses Critical Analys Discourse as conducted by Moses Alo, who uncovered discourse strategies and it was used by journalists to manipulate opinions, mobilize actions, and to influence perceptions on the Main Radio Options discourse at Osun State. ${ }^{3}$ Besides ideology, this study also analyzed aspects of language as a whole. It is based on the view that the notion of discourse is closely related to communicative situations in society. ${ }^{4}$

Based on the description above, the purpose of this study is formulated to reveal the representation of women workers in the perspectives of nationalist-secular ideology and Islamic ideology.

\footnotetext{
${ }^{1}$ Bushra Munawar, "Discourse in Matrix of Power: The Textual Analysis of First Presidential Speech by Donald. J. Trump at White House in the Context of Norman Fairclough's Modal of Three Levels of Discourse", International Journal of Applied Linguistics $\mathbb{E}$ English Litrature, Volume 7, Number 7 (2018), 80-89.

${ }^{2}$ Sudirman Tebba, Jurnalistik Baru, Jakarta: Kalam Indonesia, 2005: 3-8.

${ }^{3}$ Moses Alo and Christiana Oluremi Ajewole-Orimogunje, "Discourse Strategies and Ideology in Selected Radio Lead News of Osun State Broadcasting Corporation, Nigeria", 3L: Language, Linguistics, Literature, Volume 19 Number 2 (2013), 111-23.

${ }^{4}$ Teun A van Dijk, "Ideology and Disourse", in Michael Freeden, Lyman Tower Sargent, and Marc Stears (eds), Political Ideologies, United State of America: Oxford University Press, 2013, 210.
} 


\section{Critical discourse analysis}

In this research context, discourse refers to the understanding of the language used in communication. ${ }^{5}$ Therefore, critical discourse analysis evaluates language not only from linguistic aspects but also from the context. ${ }^{6}$ This view can also be interpreted as discourse being intertwined with the facts occurring in the community. ${ }^{7}$ In line with that, Fairclough suggests that discourse is a social practice in a certain context. Fairclough's concept can be divided into three dimensions: text, discourse practice, and social practice. ${ }^{8}$ If they are related to the discourse of news in newspapers, the texts relate to the language aspects.

Based on the description above, the definition of discourse analysis in the context of this research was formulated in a way that revealed the activities, views, and identities based on the language used in the discourse. From this definition, the analysis and interpretation of research view discourse as a social process, social practice, and as related to a particular social perspective. ${ }^{9}$ The method of this research replicates the method used in the critical paradigm of multilevel methods, ${ }^{10}$ which takes into consideration the sociocultural context and the background of a textmaking actor. One of the characteristics of critical discourse analysis is that there is an ideological point of view that comprises a system of

\footnotetext{
${ }^{5}$ Aris Badara, "Stand-up Comedy Humor Discourse in Local Perspective in Indonesia", International Jiurnal of Applied Linguistics $\mathcal{E}$ English Literature, Volume 7, Number 7 (2018), 222-28.

${ }^{6}$ Marianne Jorgensen and Louise Phillips, Discorse Analysis: As Theory and Method, London: Sage Publication, 2002.

${ }^{7}$ Per Ledin and David Machin, "Doing Critical Discourse Studies with Multimodality: From Metafunctions to Materiality”, Critical Discourse Studies, Volume 16, Number 5 (2019), 497-153.

${ }^{8}$ Marianne Jorgensen and Louise Phillips, Discorse Analysis.

${ }^{9}$ Norman Fairclough, "Critical Discourse Analysis and Critical Policy Studies", Critical Policy Studies, Volume 7, Number 2 (2013), 37-41.

${ }^{10}$ Ibnu Hamad, Konstruksi Realitas Politik Dalam Media Massa, Jakarta: Granit, 2004, 18
} 
ideas expressed in communication. ${ }^{11}$ According to Larrain, ideology can positively be perceived as a worldview that states the social value of a particular group to defend certain interests. From the negative side, ideology is seen as a false awareness to distort the understanding of people or groups about a reality. ${ }^{12}$ Furthermore, this research uses the approach developed by van Dijk. It focuses on the discursive production of abuse of power, such as sexism, racism, and various other forms of social inequality. The analysis is done through a sociocognitive process-one in which the mental representation of a social event is connected with the cognitive structure that underlies a discourse. In this study, the discourse of news in the newspaper is indispensable from the background of ideology to direct the reader towards a particular ideology. The discourse analysis model is introduced by van Leeuwen to detect and process a person or a group in a discourse. ${ }^{13}$

\section{Indonesian women workers in the perspective of news discourse}

During the period of June-December 2019, newspaper news discourse in Indonesia discussed Indonesia's chaotic legislative and presidential elections. From the perspective of discourse analysis, the news illustrates the condition of the nation, which tends to be unstable on the social, political, economic, and security levels. These conditions have implications that must be confronted by women workers, namely: (a) increasingly excluded, (b) limited space for movement, and (c) experiencing violence. This is the basis for selecting news discourse in the period of June-December 2019 as the unit of analysis for this research. The data were $6 \mathrm{RMN}$ discourses as

\footnotetext{
${ }^{11}$ Alex Sobur, Analisis Teks Media: Suatu Pengantar Untuk Analisis Wacana, Analisis Semiotik, dan Analisis Framing, Bandung: Remaja Rosdakarya, 2004, 32.

${ }^{12}$ Alex Sobur. Analisis Teks.

${ }^{13}$ Teun A. van Dijk, "Critical Discourse Analysis”, in Deborah Tannen, Heidi E. Hamilton, and Deborah Schiffrin (eds), The Handbook of Discourse Analysis 2, New Jersey: John Wiley \& Sons, Inc., 2015, 466-70.
} 
the newspaper follows the perspective of nationalist-secular ideology and 6 news discourses from $\mathrm{RN}$ as a newspaper with an Islamic ideological perspective. ${ }^{14}$ The number of 6 news discourses in each newspaper as a unit of analysis is considered sufficient because it is based on the view of Stempel, who stated that 6 samples can produce accurate analysis results as long as it is used in similar newspapers. ${ }^{15}$ In the context of this study, the intended female workers are domestic servants, factory workers, prostitutes, and seasonal workers abroad, including domestic workers, who provide services to children and parents. ${ }^{16}$ Physical and sexual violence refers to the opinion of Briere and Elliot, namely the physical and verbal temptation committed intentionally by adults to female workers. ${ }^{17}$ The accuracy of this research is also maintained because it uses oral sources in the form of interviews with mass communicators who work on RMN and RN as well as with newspaper practitioners. Oral sources are also derived from in-depth interviews with the readers who seemingly understand the phenomena and concerned with women. The data is analyzed through a discourse analysis approach in the following steps: description; the researcher outlines the discourse strategy used by the newspapers, interpretation; the researcher interprets the results of data analysis, explanation; the researcher explains the results of the interpretation.

\footnotetext{
${ }^{14}$ Ibnu Hamad, Konstruksi Realitas.

${ }^{15}$ Klaus Krippendorff, Content Analysis: An Introduction to Its Methodology, Fourth Edition, Los Angeles: Sage Publication, 2018, 120-121.

${ }^{16}$ Grace Chang, Disposable Domestics: Immigrant Women Workers in the Global Economy, Chicago, Illionis: Hymarket Books, 2016, 145.

${ }^{17}$ John Briere and Diana M Elliott, "Prevalence and Psychological Sequelae of Self-Reported Childhood Physical and Sexual Abuse in a General Population Sample of Men and Women”, Child Abuse ES Neglet, Volume 27, Number 27 (2003), 1205-22.
} 


\section{Discourse analysis of news on RMN}

\section{Data below used the identification discourse strategy}

(1) The obscene event began with a mouth quarrel that occurred because Nn refused to fulfill Y sex appeal. The next day, Saturday, when Nn was not at home.

Data (1) above shows identification because Nn refused to fulfill Y sex appeal. Such identification can be interpreted as Y raping Yn because his sex invitation was rejected by $\mathrm{Nn}$. From the perspective of critical discourse analysis, the woman was seen as a sex object obligated to serve the man's sexual needs. Such identification shows that $\mathrm{Y}$ immorality as an actor hidden by the newspaper in the text. The alignment of the newspaper to $Y$ and the Yn marginalization was also reflected in the vocabulary used, namely event. The word means indecent acts carried out together.

The next explanatory sentence showing the identification of newspaper tended to marginalize Yn position as follows.

(2) Without asking many questions, Yn just obeyed. When she was in the room, without further ado, Y immediately hugged $Y$ n.

Identification data (2) was in the form of a sentence without asking many questions, Yn just agreed. The sentence was the explanation of the previous proposition. The context of the sentence showed that it was impossible for Yn not to know her employer's intention when who told her to enter the bedroom. Therefore, explanatory sentences of "without many questions, Yn just obeyed," was a sentence that marginalized Yn position as a woman. The identification discourse strategy was also found in the data below.

(3) Because of losing power, Yn was immediately weakened. Quickly, Y striped the woman so that not a single thread closed her beautiful body. In a moment, he kissed and touched $Y$, then he raped her until satisfied. 
Identification in the form of the sentence "because of losing power, Yn was immediately weakened," describe that Yn was an actor who was physically weak and did not have the power to defend herself. Even shown is the fact that she did not show any resistance when Y stripped her. By using identification discourse strategy, the marginalization of Yn was also reflected in the sentence, '... stripped the woman so that not a single thread closed her beautiful body.' The sentence was very sensational and the event was dramatized. Moreover, the newspaper used the word choice 'Yn beautiful body,' as if the audience was invited to "enjoy" Yn's body. Kissing vocabulary used in data (3) also marginalized Yn. The choice of words in the context of the sentence illustrates the passivity of Yn, which means she was kissed many times without resistance.

Some data related to the implementation of the identification discourse strategy can be seen in the following discourse data.

(4) ... Unable to stem libido, this man allegedly had raped his servant in his bathroom

Data (4) affirmed the interpretation that the employer raped his servant not because of his moral depravity, but because of his libido drive. The subordinate clause, "unable to stem libido," covered the moral depravity of the employer. The newspaper showing bias towads the actor/employer was also marked by the use of vocabulary "strongly supposed," which means that the rape had not been proven to be done by the employer.

(5) While taking a bath, Ef saw Nr who was washing something in the bathroom, which might be the time when bad thoughts emerged to taste the body of a bright sexy girl.

The identification given by the newspaper on data (5) was expessed in "which might be the time when bad thoughts emerged in to taste the body of a bright sexy girl." It means that Ef-the real actor-did 
not have the intention of raping $\mathrm{Nr}$. His willingness emerged after seeing N'r sexiness in the bathroom. Such thing can be interpreted by the reader as rape being carried out by the employer due to Nr's sexy body instead of libido 'and unsatisfactory wife services.'

Nr's position was increasingly marginalized by the "to taste" vocabulary used by the newspaper because the word is only used as a verb in recognizing the flavor of food. Thus, the meaning of data (5) turns $\mathrm{Nr}$ into an object similar to a portion of food that can be tried as desired. Further identification provided by the newspaper, which tended to place victims as one of the causes of sexual violence, was due to their limitations. This can be seen in the following data.

(6) Ef pulled Nr into the bathroom, Nr was suddenly shocked to find herself naked with Ef in the bathroom.

It was impossible if $\mathrm{Nr}$ did not realize that she was suddenly naked in the bathroom. Therefore, the readers capture that $\mathrm{Nr}$ wanted to be raped. This was confirmed by identification because of fear, ... in the following data (7).

(7) ... because of fear, even though she was treated indecently, $\mathrm{Nr}$ did not resist.

The next identification given to the actor/employer was to have power, and strength as shown below.

(8) At that time, $\mathrm{Nr}$ could not do anything. The woman could not maintain her virginity which was forcibly taken away by her employer.

The data (8) above illustrated the powerlessness of $\mathrm{Nr}$, which was under the arbitrariness of Ef. She did not have the power to be able to maintain something worthwhile. It was described that she lost her virginity very tragically and painfully as the identification words of forcibly were taken away.

(9) ... the old man often committed indecent acts to her, by trying to rape herself who was indeed sexy. 
The discourse strategy used to marginalize Ek as a victim was an identification discourse strategy. The identification provided by the newspaper is indeed 'sexy.' This identification can lead the reader to the meaning that what triggered the indecent behavior was Ek's sexiness. The following data (10) also identified Ek as an actor in the text that was not alert in anticipating events that would happen to her.

(10) Without further ado, he immediately hugged Ek and peppered her face. Even though she was sleeping, Ek woke up, then pushed Ak body which was already above her body ...

(11) When confused, Sp met Ad. He realized that Sp was a migrant worker who had just returned from abroad. He thought that Sp brought a lot of money and he could use it.

The identification discourse strategy used in data above was indicated by identification when confused. This indication placed $\mathrm{Sp}$ as the main cause of mistakes and as a sex object. The use of the identification discourse strategy was also shown in the data below.

(12) Without suspicion, Sp immediately agreed to get the tantalizing offer. But instead of delivering home to Kendal, ....

Without suspicion, an identification given by a newspaper shows that $\mathrm{Sp}$ did not have good cognitive abilities. The identification marginalized $\mathrm{Sp}$. Likewise, the tantalizing vocabulary used gave a bombastic impression and marginalized victims.

(13) Because of exhaustion, this innocent woman finally obeyed Ad's wishes ....

Data (13) used categorization discourse strategies. The categorization used was an innocent woman who could be interpreted based on her innocence. Sp wanted to obey Ad's request to stay in his house. The following data was the implementation of identification discourse strategy. 
(14) Once tried, Ad turned out to be addicted to 'taste' the beauty of the body of a young mother from Kendal ....

The identification used by the newspaper was once tried to create a sensational impression. Likewise, the vocabulary used was "to taste," which could be interpreted as a sacrifice of delicious food. Rape, for the victim, was a form of sexual abuse that was very painful physically and psychologically.

(15) The two foreigners knew that the house was only guarded by a woman servant.

The identification of data (15) was the text of only maintained by a woman servant. The robbery may be triggered by other things, not only the female servant's surveillance. In fact, the adverbs clearly contained marginalization as if the robbery happened due to the female servant's surveillance.

The following data was the implementation of the categorization discourse strategy.

(16) Petite Gy suddenly could not do anything. A moment later ....

Petite categorization is not significant for the reader because it does not affect the meaning of the text above. However, it indirectly provided an association because Gy was petite. So, she could not do anything to the robber. The marginalization of Gy was also illustrated in the following text.

(17) When in the kitchen, a robber who led Gy was tempted by the beauty of Gy's body. At that moment, the robber raped her in the kitchen.

The newspaper provided identification that the robber initially did not intend to rape Gy. Because he was tempted by Gy's body, he intended to rape her. Such identification could affect the public's perception that rape occurred because of Gy's body.

Trends in the direction of RMN representation based on discourse analysis

As one of the newspapers that considered itself "The fire of Indonesian democracy,” Rakyat Merdeka represented women actors as weak, sexy, 
seductive, often feeling guilty, innocent, and easily seduced. Although these events were sometimes casuistic, RMN often generalized them. Conversely, the actor/employer was represented in the text as positive, intelligent, and strong and gave justification for his actions, which seemed to be covered with moral depravity.

Based on the above issue, it can be concluded that the RMN has made a misrepresentation of woman actors in the news discourse. The misrepresentation was done by ex-communication, a strategy that raised woman actors in news discourse, but the "voice" was not heard. The storytelling point of view was generally from the editor and the perspective of the actor.

From the perspective of marginalization practices, RMN described women actors in their news discourse improperly-use of particular vocabulary, completing lust, obscene events, "tasting" bright girls, venting lust, desire to have intercourse, tempting body elegance, and curvaceous. The practice of marginalization was classified into the discourse strategy of dysphemism. It is the use of language resulting in the reality of becoming abusive. Besides dysphemism, RMN also used stereotyping strategies that showed negative traits towards women actors such as weak, quick to surrender, timid, innocent, keen on teasing employers, and so on. This shows that in Indonesia there is still a gender inequality as Koo saidthe dominance of men over women is an illustration of understanding excessive gender inequality. ${ }^{18}$

From the whole description above, it can be concluded that RMN marginalized women's position in the news discourse, which emphasizes their patriarchal character.

\footnotetext{
${ }^{18}$ Eunjung Koo, "Women 's Subordination in Confucian Cultur: Shifting Breadwinner Practices”, Asian Journal Women's Studies, Volume 25, Number 3 (2019), 417-36.
} 


\section{Discourse analysis of news on the RN}

The following data is the implementation of the nomination discourse strategy.

(18) The victim's father, A, revealed that the news of her first child death was received from $\mathrm{M}$, his second daughter who also became migrant workers in the employer's family C. According to M, C drowned at sea behind their employer's home while dumping garbage.

Although data (19) did not marginalize $\mathrm{C}$ and $\mathrm{N}$ as the victims, the newspaper tended to hide the actor in the text. It was visible in the data (19) below.

(19) ... A said that he and his wife, Dk (40 years), did not know the name of the Labor Services Recruitment Company of Indonesia (PJTKI) which dispatched his two children out of the country, ....

The actor in the aforementioned issues mentioned their status as an employer so that the audiences would not know his/her identity. Similarly, the recruitment company, which sent $\mathrm{C}$ and $\mathrm{N}$, was unknown. It might have been due to the laziness of journalists or editors to browse information related to the events experienced by $\mathrm{C}$. The results showed that there was no information about the actors in the text.

The following data used nomination discourse strategy and it did not marginalize the victims. However, the actor only mentioned his/ her status as an employer so that the audience would not know his/ her identity. Similarly, the agency was also only mentioned by name as well as a fellow housemaid, who raped $\mathrm{K}$, was kept anonymous. It might be due to the laziness of journalists to explore the actor's information.

(20) Kalso reported experiencing sexual abuse from a man worker of Jordanian citizens. When complaining to her employer, she was accused of doing slander. Kescaped and finally went back to the agency which brought her to the City of Amman. 
The following data generally displayed $\mathrm{K}$. So, the data were categorized into nominations discourse strategy.

(21) My employer told me that I would be on the fence, "K said while demonstrating a hand to her neck like a scene cut. "I mean, the death penalty was from the ninth employers who threatened to kill and throw me to Palestina ...."said Kasem who still looked shocked.

Found was data that marginalized the victims. Two quotes marginalized the position of $\mathrm{K}$ as a victim of violence of her employer. Marginalization was conducted by RN by using a categorization discourse strategy as shown in the following quote.

(22) The innocent woman could only surrender and seek refuge in Allah. Surprisingly, when $K$ was reading Al-Qur'an, she was accused of enchanting the employer.

The quote above used categorization discourse strategy through the use of the innocent women category. Such categorization provided an opportunity for employers to do physical violence beyond the limits of humanity towards $\mathrm{K}$. The reporting category of innocent women to the victim did not provide additional information on who $\mathrm{K}$ was. The result of the editor's research showed that there was no intention to show the innocent nature of $\mathrm{K}$. However, indirectly, it might create an impression of marginalization against $\mathrm{K}$.

Another identification discourse strategy was found in the following data.

(23) Kalso suffered sexual harassment from the male worker of Jordanian citizens in the employer's house. "He had raped me," she said.

The identification "he had raped me" led the news to be received by audience badly. The bad impression of the audience was captured from the victim who was not uncomfortable to reveal rape by her employer. A direct statement of the victim cited by the newspaper intended to invite sympathy to the treatment suffered by her. However, an educated audience could leave a negative impression. 
The discourse strategy used was nominations discourse strategy and no text in which Sinta was marginalized as a victim was found. However, Sinta became the object of news.

(24 Sinta, from Cigadog village, Sukajaya village, District Tanggeung, southern Cianjur, West Java, lost her eyesight because of being too often tortured by her employer, Hisham Munawar Ma'sum.

Other data can be expressed as follows.

(25) ... Todung assessed the UCI (United Corporation Insurance) should be responsible for such cases because PJTKI PT DGU had appointed such protection agencies to protect Sinta, by paying insurance premiums.

Although the data (30) did not marginalize the victim, it showed another actor whose presence defended the interests of PT DGU -not Sinta's interests. Such data pattern also appeared in the following data.

(26) President Director of PT DGU, Yus Umar Assegaf, said that Sinta went to Saudi Arabia in January 2005 and in November 2005, she went back intragenic condition. 'We had spent a lot of money to repatriate and treat Sinta, he said.

The following data (27) was not found in marriages, but only as the object of reporting. Therefore, the following data was categorized into nomination discourse strategy.

(27) Rohana herself, during the trial, pleaded guilty to the act that caused the death of Tan Chiang Eng at the residence of her employer. Preceded by a fight between the accused and the victim .... It was also revealed that, since there was employment, Rohana was used to be treated poorly by her employer, according to the Indonesian Embassy in Singapore. Although women were one of the actors who had experienced violence displayed by using objectivation discourse strategy in the analysis of the data, there was no impression of marginalization. Similarly, although the content of the news was not shown in the news content of Indonesian women workers, it was not marginalized. The cause was that their voices were represented by other actors. 
Trends in the direction of $R N$ representation based on discourse analysis With the visions of nation's intellectual development, cultural development, and an increase in faith and piety in new Indonesian life, $\mathrm{RN}$ represented women actors as they were exactly. It even invited people to show solidarity for women workers who experienced violence from their employers. It was reflected in the language used, which tended to be neutral and it did not contain sensational meaning.

In the analysis of news discourse data, there was no misrepresentation. Women actors were generally invited to speak in the news discourses. The actors in the $\mathrm{RN}$ were generally represented through the use of exclusion discourse strategies. However, it was not impressive if the actors were protected. It was only journalists who cannot trace its existence, so the actors' identity was mostly unknown.

Based on the aforementioned ideas, it can be concluded that RN has defended women's rights. It is in accordance with the vision and mission followed by the owners of RN, namely nationality, democracy, and Islamism. The vision was to be a nationally integrated printed media company and professional management based on Islamic belief. So, it influenced the nation's intellectual development, cultural development, and an increase in faith and piety in new Indonesian life.

\section{Representation of women workers in RMN as newspapers of na- tionalist-secular ideology}

As a newspaper informed by nationalist-secular ideology, RMN represented women in a marginal position. ${ }^{19}$ It could be seen in the negative identification given to women as victims. Identification given to women as victims of employer violence was negative, such as 'sexy,' 'without any questions,' 'the body of a bright-skin girl,' 'because of silence,' 'an innocent

\footnotetext{
${ }^{19}$ Ibnu Hamad, Konstruksi Realitas.
} 
woman can do nothing,' 'a curvaceous backing.' On the contrary, the actor (employer) was represented as smart, 'dissatisfied with the wife's service,' 'unable to resist libido,' 'aroused by the plump buttocks,' 'has a strategy,' 'because of being jazzed.' Such a representation seemed to be in defense of the employer's depraved actions against his servants. The vocabulary used also tended to be sensational and often dramatized rape, obscenity, kissing, tasting, naked, seductive, and so on. The use of such vocabulary can be included as an ism that makes practical use of linguistics. ${ }^{20}$ These terms are also ironic because they are only used by colonials in colonies that consider eastern women as exotic bodies that are to be conquered. ${ }^{21}$

RMN's practice of discourse appears to place women in a marginal position. It implies a division between the man (employer) and the woman as the servant as well as the victim of employer violence. The result of such a practice was a poor depiction of women as victims. Therefore, it could be said that RMN did not describe women as they were supposed to be, but rather identified them with subjective explanations.

The language used in the marginalization of women was dysphemism, which could lead reality to be rude. The results of an interview with the editor of RMN showed that the use of dysphemism language was intended to make the language used differently from other newspapers. Those relating to negative portrayals of women were intended by editors to be used as an example of women workers.

The women representation in the discourse of news on RMN could have negative implications for women's position because they could form negative stereotypes about women. These concerns are based on the view that newspapers can form the public perceptions, certain beliefs, and

\footnotetext{
${ }^{20} J u s s i$ Kurunmäki and Jani Marjanen, "Isms, Ideologies and Setting the Agenda for Public Debate", Journal of Political Ideologies, Volume 23, Number 3 (2018), 256-82.

${ }^{21}$ Wening Udasmoro, "The Language Construction of Muslims as the Others in French", Indonesian Journal of Islam and Muslim Societies, Volume 7, Number ( 2017), 77-99.
} 
certain political views. ${ }^{22}$ Besides, the common attitude in Indonesian society did not critically accept the facts and opinions offered by the media.

Besides 'market' motive, women's negative representation is also caused by patriarchal ideology, which has long been rooted in Indonesia. In fact, the ideology of patriarchy is assumed to be the opposite or negation of feminism ${ }^{23}$ and has become a natural and normal thing to happen. This finding is reinforced by the opinion that the hegemony of strong groups against weak groups is common. ${ }^{24}$ In fact, it has become a social doctrine in society. ${ }^{25}$

The other thing affecting the marginalization of women in RMN discourse was that the influence of the Indonesian press industry was still an issue of patriarchy. Moreover, it is also influenced by the dominance of men in all social institutions including the press industry. ${ }^{26}$ This statement is in line with LP3Y's findings that Indonesia was almost declared as a man's world, leading to the news being more masculine. ${ }^{27}$ Such conditions are very dangerous considering the role of the media being very important in shaping discursive dynamics. ${ }^{28}$

\footnotetext{
${ }^{22}$ Mikko Villi and Kaori Hayashi, "The Mission Is to Keep This Industry Intact: Digital Transition in the Japanese Newspaper Industry”, Journalism Studies, Volume 18, Number 8 (2015), 1-18.

${ }^{23}$ Redi Panuju, Daniel Susilo, and Harliantara, "Cigarette as a Tool for Representing Masculinity in Indonesian Left-Wing Films", Komunikasi Indonesia, Volume VII, Number 3 (2018), 246-257.

${ }^{24}$ Sarah Day, Josephine Cornell, and Nick Malherbe, "Discourses of 'Service Delivery Protests' in South Africa: An Analysis of Talk Radio Analysis of Talk Radio", Critical Discourse Studies, Volume 16, Number 5 (2019), 1-18.

${ }^{25}$ Koeswinarno and Musttolehudin, "Islam, Gay, and Marginalization: A Study on the Religious Behaviours of Gays in Yogyakarta", Indonesian Journal of Islam and Muslim Societies, Volume 7, Number 1 (2017), 125-52.

${ }^{26}$ Muhammad M Haj-yahia, "Beliefs About Wife Beating Among Arab Men From Israel: The Influence of Their Patriarchal Ideology”, Journal of Familiy Violence, Volume 18, Number 4 (2003) 193-206.

${ }^{27}$ LP3Y, Sewindu Republika Harian Umum Republika, Jakarta: Republika, 2005.

${ }^{28}$ Franco Zappettini and Michał Krzyżanowski, "The Critical Juncture of Brexit in Media \& Political Discourses: From National-Populist Imaginary to Cross-National Social and Political Crisis”, Critical Discourse Studies, Volume 16, Number 4 (2019), 381-388.
} 


\section{Representation of women workers in RN as newspapers of Islamic ideology}

$\mathrm{RN}$ was concluded as a newspaper with Islamic ideology because the founding process could not be separated from the Association of Indonesian Muslim Scholars (ICMI). ICMI is not only an association of Muslim scholars but also an association of Islamic political power. In fact, Indonesia is a country with a Muslim majority population, and the media becomes a forum to spread Islamic ideology as a way of life. ${ }^{29}$ It was supported by the statement that RN embraced the ideology of its owner, PT Abdi Bangsa, namely nationality, democracy, and Islamism. ${ }^{30}$ This ideology influenced women's representation in the news discourse.

$\mathrm{RN}$ described women who experienced violence as they were exactly. The case experienced by women was advocated by the RN. It might be an implication of the vision and mission of the, namely to be a nationally integrated printed media company and professional management based on Islamic beliefs. So, it influenced the nation's intellectual development, cultural development, and accounted for an increase in faith and piety in new Indonesian life. This is supported by the intellectual mission that follows:

The missions of RN are: (a) to educate the nation by deepening community-based insights through accurate, actual, reliable, educative reporting, and to defend justice and truth. The women representation in news discourse on RN, displayed as the way it, was influenced by the motto, "not just selling the news." ${ }_{11}$ This is in line with the findings of CMI BRIEF that Islam has so far been identified as a cause of exclusion

\footnotetext{
${ }^{29}$ Muzayyin Ahyar and Alfitri, "Aksi Bela Islam: Islamic Clicktivism and the New Authority of Religious Propaganda in the Millennial Age in Indonesia”, Indonesian Journal of Islam and Muslim Societies, Volume 9, Number 1 (2019), 1-29.

${ }^{30}$ Ibnu Hamad. Konstruksi Realitas.

${ }^{31}$ LP3Y. Sewindu Republika.
} 
of women, even though the facts show that Islam advocates an increase in the presence of women in society. ${ }^{32}$ The findings support an approach that women feel empowered through a male-dominated environment. ${ }^{33}$

\section{Conclusion}

The findings of this article were the representation of women workers in news discourse in newspapers, which approved by the ideology carried by each newspaper. As a newspaper informed by a nationalist-secular ideology, RMN represented female workers in marginal positions, while $\mathrm{RN}$, as a newspaper carrying Islamic ideology, provided advocacy for women workers in its news. From the point of view of reporting, there are certain differences. RMN reported from the perspective of the victim, so the public focused on the victim and was released. Meanwhile, RN rebelled from the point of view of victim advocacy. These findings, which showed the analysis of critical discourse, could demolish the hidden aspects behind the news discourse. Therefore, critical discourse analysis was used more intensely in the field of social field research for the sake of criticism and transformation. As a recommendation for discourse research, it is necessary to link and develop social and cultural factors and social theories of history behind the text. This needs to be done because of the wide range of socio-cultural issues related to texts and discourse.

\section{Bibliography}

Ahyar, Muzayyin, and Alfitri, "Aksi Bela Islam: Islamic Clicktivism and the New Authority of Religious Propaganda in the Millennial Age in Indonesia", Indonesian Journal of Islam and Muslim Societies, Volume 9, Number 1 (2019):

${ }^{32}$ Liv Tønnessen and Samia Al-Nagar, Gender Equal Reform Sudan After the Comprehensice Peace Agreement in Book Workshop on the Women and Peacebuilding in Africa Project, New York: CMI, 2019: 13.

${ }^{33}$ Katie Christine Gaddini, "Between Pain and Hope: Examining Women's Marginality in the Evangelical Context”, European Journal of Women's Studies, Volume 26, Number 4 (2019), 405-20. 
$1-29$.

https://doi.org/https://doi.org/10.18326/ijims.v9i1.1-29

Alo, Moses, and Ajewole-Orimogunje, Christiana Oluremi, "Discourse Strategies

and Ideology in Selected Radio Lead News of Osun State Broadcasting

Corporation, Nigeria”, 3L: Language, Linguistics, Literature, Volume 19,

Number 2, (2013): 111-23.

https://doi.org/http://ejournals.ukm.my/31/article/view/1227

Badara, Aris, "Stand-up Comedy Humor Discourse in Local Perspective in Indonesia", International Journal of Applied Linguistics and English Literature,

Volume 7, Number 7 (2018): 222-28. https://doi.org/https://www. journals.aiac.org.au/index.php/IJALEL/article/view/5055/3787

Boulahnane, Saad, "Ground Zero Mosque in the Context of America's Post-9/11

Religious Pluralism: CDA of Mainstream News Media's Coverage of the Discursive Event", Indonesian Journal of Islam and Muslim Societies, Volume 8, No. 2 (2018): 253-80 https://doi.org/10.18326/ijims.v8i2.253279.

Briere, John, and Elliott, Diana M, "Prevalence and Psychological Sequelae of

Self-Reported Childhood Physical and Sexual Abuse in a General Population

Sample of Men and Women”, Child Abuse E Neglect, Volume 27, Number

27 (2003): 1205-22. https://doi.org/10.1016/j.chiabu.2003.09.008

Chang, Grace. Disposable Domestics: Immigrant Women Workers in the Global Economy.

Chicago, Illionis: Hymarket Books, 2016.

https://books.google.co.id/s?hl=en\&lr=\&id=QdxeDAAAQBAJ\&oi=fnd\&pg= PR7\&dq=WOMEN+WORKERS

Day, Sarah, Cornell, Josephine, and Malherbe, Nick, "Discourses of 'Service Delivery Protests' in South Africa: An Analysis of Talk Radio Analysis of Talk Radio”, Critical Discourse Studies, Volume 16, Number 5 (2019): 1-18. https://doi.org/10.1080/17405904.2019.1676279

van Dijk, Teun A., "Critical Discourse Analysis", in Deborah Tannen, Heidi E. Hamilton, and Deborah Schiffrin (eds.), The Handbook of Discourse Analysis 2. New Jersey: John Wiley \& Sons, 2015. https://doi. org/10.1002/9781118584194

Fairclough, Norman, "Critical Discourse Analysis and Critical Policy Studies", Critical Policy Studies, Volume 7, Number 2 (2013): 37-41. https://doi.org /10.1080/19460171.2013.798239

Gaddini, Katie Christine, “Between Pain and Hope: Examining Women's Marginality in the Evangelical Context", European Journal of Women's Studies, Volume 26, Number 4 (2019): 405-20. https://doi.org/https:// 
IJIMS: Indonesian Journal of Islam and Muslim Societies, Volume 10, Number 1, June 2020: 79-101

doi.org/10.1177/1350506819846167

Haj-yahia, Muhammad M, "Beliefs About Wife Beating Among Arab Men From Israel: The Influence of Their Patriarchal Ideology", Journal of Familiy Violence, Volume 18, Number 4 (2003): 193-206. https://link.springer.com/ article/10.1023/A:1024012229984

Hamad, Ibnu. Konstruksi Realitas Politik Dalam Media Massa. Jakarta: Granit, 2004. Jorgensen, Marianne, and Phillips, Louise, Discourse Analysis: As Theory and Method. London: Sage Publiation, 2002. https://books.google.co.id/ books?hl=en\& $\& \mathrm{r}=\& \mathrm{id}=\mathrm{tK} 64 \mathrm{gl} 3-\mathrm{i} 4 \mathrm{oC} \& \mathrm{oi}=\mathrm{fnd} \& \mathrm{pg}=\mathrm{PP} 1$

Koeswinarno, and Musttolehudin, "Islam, Gay, and Marginalization: A Study on the Religious Behaviours of Gays in Yogyakarta", Indonesian Journal of Islam and Muslim Societies, Volume 7, Number 1 (2017): 125-52. https:// doi.org/10.18326/ijims.v7i1.125-152>

Koo, Eunjung, “Women's Subordination in Confucian Culture: Shifting Breadwinner Practices Women 's Subordination in Confucian Culture: Shifting", Asian Journal Women's Studies, Volume 25, Number 3 (2019): 417-36. https://doi.org/10.1080/12259276.2019.1648065

Krippendorff, Klaus. Content Analysis: An Introduction to Its Methodology. Fourth Edition (ed) Terri Accomazzo. Los Angeles: Sage Publication, 2018. https:// books.google.co.id/s?hl=en\&lr=\&id=nE1aDwAAQBAJ\&oi=fnd\&pg=PP1 $\&$ dq $=$ krippendorff

Kurunmäki, Jussi, and Marjanen, Jani, "Isms, Ideologies and Setting the Agenda for Public Debate”, Journal of Political Ideologies, Volume 23, Number 3 (2018): 256-82. https://doi.org/10.1080/13569317.2018.1502941

Ledin, Per, and Machin, David, "Doing Critical Discourse Studies with Multimodality: From Metafunctions to Materiality", Critical Discourse Studies, Volume 16, Number 5 (2019): 497-153. https://doi.org/10.1080/17405 904.2018.1468789

LP3Y. Sewindu Republika Harian Umum Republika, 2005.

Munawar, Bushra, "Discourse in Matrix of Power: The Textual Analysis of First Presidential Speech by Donald. J. Trump at White House in the Context of Norman Fairclough's Modal of Three Levels of Discourse", International Journal of Applied Linguistics $\mathcal{E}$ English Litrature, Volume 7, Number 7 (2018): 80-89. https://doi.org/http://dx.doi.org/10.7575/aiac.ijalel.v.7n.7p.80

Panuju, Redi, Susilo, Daniel and Harliantara, "Cigarette as a Tool for Representing Masculinity in Indonesian Left-Wing Films", Komunikasi Indonesia, Volume 7, Number 3 (2018): 246-57. http://repository.unitomo. ac.id/id/eprint/1523 
Sobur, Alex. Analisis Teks Media: Suatu Pengantar Untuk Analisis Wacana, Analisis Semiotik dan Analisis Framing. Bandung: Remaja Rosdakarya, 2004.

Tebba, Sudirman. Jurnalistik Baru. Jakarta: Kalam Indonesia, 2005.

Teun A, van Dijk. Ideology and Disourse, in Michael Freeden, Lyman Tower Sargent, and Marc Stears (eds) Political Ideologies. United State of America: Oxford University Press, 2013. https://books.google.com.hk/books?id=ObEAAAAQBAJ\&pg=PT460\&lpg

Tønnessen, Liv and al-Nagar, Samia, Gender Equal Reform Sudan After the Comprehensince Peace Agreement, in Book Workshop on te Women and Peacebulding in Africa Project. New York: (CHR Michelsen Intitute), 2019. https://www. cmi.no/publications/7005-gender-equal-reform-in-sudan

Udasmoro, Wening, "The Language Construction of Muslims as the Others in French", Indonesian Journal of Islam and Muslim Societies, Volume 7, Number (2017), 77-99. https://doi.org/10.18326/ijims.v7i1.77-99

Villi, Mikko, and Hayashi, Kaori, "The Mission Is to Keep This Industry Intact: Digital Transition in the Japanese Newspaper Industry", Journalism Studies, Volume 18, Number 8 (2105), 1-18. https://doi.org/10.1080/146167 OX.2015.1110499

Zappettini, Franco, and Michał Krzyżanowski, "The Critical Juncture of Brexit in Media \& Political Discourses: From National-Populist Imaginary to CrossNational Social and Political Crisis", Critical Discourse Studies, Volume 16, Number 4 (2019), 381-388 <https://doi.org/10.1080/17405904.2019.15 92767> 
